\title{
Madárnévből származó lőfegyvernevek
}

Az alábbiakban madárnévből, mégpedig solymászmadarak (pedzőmadarak) nevéből származó löfegyverneveket (közneveket) tárgyalok, azaz a falkon, falkonett, muskéta és terzerol elnevezések - vándorszók - azonos szemléleten alapuló keletkezésére mutatok rá, elsősorban A. J. STORFER nyomán. Keletkezésük háttere egyrészt az a szemlélet, hogy a fegyverek úgy ártanak az embereknek, ellenségnek, mint a sólymok áldozataiknak, másrészt az, hogy a madár is nagy sebességgel, suhogva támad, szinte rálövi magát áldozatára, a golyó is suhogva repül. Így a lőfegyverek megszemélyesítve, metaforikusan solymászmadarak. A négyből két szó közvetlenül német, kettő olasz jövevényszó, mindegyik avult kifejezés, fegyvertörténeti szakszó, csak a muskéta valamelyest köznyelvi. A moldvai születésű ADOLF JOSEF STORFER (1888-1944) osztrák nyelvész (és pszichoanalitikus) a négy tárgyalandó szó német megfelelői (Falkaune, Falkonett, Muskete, Terzerol) keletkezésének azonos hátterére mutatott rá (1937: 115-116).

A lövegek elkeresztelése már a tüzérség korai időszakától szokásban volt, s a nevet a lövegek mérete és alakja határozta meg. Az ostromágyúkat ragadozókról (krokodil, farkas) vagy mesebeli állatokról (sárkány, griff), esetleg más, nagy testü állatról (bika), a tábori ágyúkat pedig a kisebb békáról, hüllőkről (kígyó, gyík), illetve madarakról (fülemüle) nevezték el. Egyesek az idők folyamán típusnevekké léptek elő, mint német nyelvterületen a Basiliskus ('sárkánygyík'), Nachtigall ('fülemüle'), a magyarban pedig a kígyó (a német Schlange mintájára).

A falkon a 15-17. században használt, '6-8 fontos golyót vetö, 23-30 mázsát nyomó tábori ágyú' volt (TEMESVÁRY 1997: ii). Más források szerint 8-33 mázsa súlyú volt, azonban az ágyúk technikai jellemzőinek közlése a forrásokban következetlen, a mértékek bizonytalanok. A falkon szó - falkony alakváltozattal - 1557-tól adatolható a magyarban, a korai újfelnémet falcon átvétele. A szó forrása a vulgáris latin falco (> olasz falco, falcone, francia faucon) 'sólyom'. A vulgáris latin szó viszont a germánból (ófelnémet falcho, középfelnémet valke, újfelnémet Falke) jön. A falkon szót eredeztették az olaszból is. A madárnévből a 16. század elejétől alakult ki a fegyvernév. (Német eredeztetése: HoRVÁTH 1978: 60-61; Mollay 1982: 256. Olasz eredeztetése: TESz. 1: 836; EWUng. 1: 354. Egyaránt feltehető olasz és német eredet: KARINTHY 1947: 37.)

A falkonett (vagy falkonéta) a 16-17. században használt, 'kisebb ágyúfajta' volt, amellyel 1,5-2 fontos golyókat vetettek ki (TEMESVÁRY 1997: ii). A falkon kicsinyítő képzős fejleménye, a falkonett északolasz jövevényszó, s alakváltozatai (falkonata, falkonéta stb.) 1520-tól adatolhatók a magyarban (KARINTHY 1947: 38; TESz. 1: 836; EWUng. 1: 353-4; a falkonett szó alakváltozatait a falkony változataiként tárgyalta HORVÁTH 1978: 60-61). A szó az északolaszban falconètt, falconetto, falcunetto változatokban létezett. A franciában faucon 'sólyom; falkon' és itteni kicsinyítő képzővel fauconneau 'fiatal sólyom; falkonett', s volt fauconnel 'falkonett' is. BABOS KÁLMÁN magyarázó szótárában még szerepel: ,falkonet, kis ágyu” (1865: 131). (A korábbi, falkony címszó alatt készített etimológiáktól - TESz.; HoRVÁTH 1978; MOLLAY 1982 - eltérően az EWUng. már külön tárgyalja a falkonéta és falkony szókat.) 
A muskéta 'kétágú villára támasztott puskaféleség' volt, amely a harmincéves háború (1618-1648) idején terjedt el. Kanócos, kerekes, kovás szerkezettel is használták, s mint egyszerü és jól bevált fegyvert még a 18. században is megtartották (TEMESVÁRY 1997: iv). A tulajdonképpeni muskéta szó 1606-tól adatolható a magyarban, több alakváltozata közül a muskotyr és a muskater 1605-ben jelent meg nyelvünkben. A magyarba a szó a németböl (Muskete 'muskéta', Muskatier, Musketier 'muskétás') került, oda az olaszból (moschetto). A német szókat átvevő magyarban a 17. században muskéta, muskatér és muskatély egyaránt 'puskafajta' volt; muskatér, muskétás, muskatéros és muskatélyos pedig 'ilyen puskával felszerelt katona'. A muskéta előzménye egy karvalyfajta neve volt, a spanyol mosquet, francia émouchet elnevezés a madár pettyezett mellére (esetleg a többi solymászmadárhoz képest kicsinységére) utal (spanyol mosca, francia mouche 'légy'). Később vált számszeríj, majd a puskafajta jelölöjévé. 1567-ben kezdték használni a spanyolok mosquete alakban, innen terjedt el más nyelvekben, így a franciában (mousquet, mousquette), az olaszban, a németben stb. (TESz. 2: 979; HORVÁTH 1978: 147-149; EwUng. 2: 1005). BABOS KÁLMÁN magyarázó szótárában egyszerủen így szerepel: „musketa = puska” (1865: 215). A muskéta, flinta ('katonai és vadászpuskafajta') és karabély ('rövid csövü puska') szavak mai jelentései egyaránt 'régi, avult puskaféleség', s mindhárom 17. századi német jövevényszó a magyarban (HORVÁTH 1978).

A terzerol a 17-19. században, elsősorban német nyelvterületen népszerü 'elöltöltő kis pisztoly' volt. Első regisztrált hazai (erdélyi) előfordulása: terczerol (1714; SzT. 13: 120). BABOS KÁLMÁN magyarázó szótárában „terzerol, ol[asz], zsebpisztoly, mordály” (1865: 301). Még a 20. század első felében is használták madarak riasztására. Egyes példányait régiségkereskedők máig árulják Magyarországon is. A szó az olasz terzolo (vagy terzuolo) 'egy solymászatban használt héjafajta hímje' elnevezéséből való, az olasz szó pedig talán a latin tertius 'harmadik' szóra vezethető vissza (kicsinyítő képzővel: *tertiolus). Ennek a több nyugat-európai nyelvböl (középfelnémet terzel, terze, terz; ófrancia tercel, tiercel; angol tercel, tiercel) ismert solymászmüszónak alapja vagy az a hiedelem, hogy ennek a madárnak a fészkében minden harmadik fióka hím, vagy az a tény, hogy e héjafajta tojója egy harmaddal nagyobb a hímnél.

EVA F. KITTAY hídterminusnak (bridge term) nevezte azokat az elnevezéseket, amelyeket először használnak metaforikusan bizonyos szómezőkből más szómezőkbe átvezetve, s további metaforák alapjául, mintájául szolgálnak (KITTAY 1987: 152). Ilyen hídterminusok voltak a tüzérség korai történetében az ágyúknak adott, állatokról vett tulajdonnevek, különösen azok, amelyek típusjelölökké váltak, majd a solymászmadarak nevéből lett lőfegyvernevek esetében a vulgáris latin falco 'sólyom', a falkon szó eredetijének megalkotásakor.

Érdekes egybeesés, hogy a solymászat hanyatlása éppen a lőfegyverek fejlődésével függ össze. A solymászat Nyugat-Európában az 5. században, a népvándorlás hun-germán hullámával jelent meg és vált fokozatosan népszerüvé. Fénykora a középkorban volt, s évszázadokon át (a lőfegyverek tökéletesedéséig) ténylegesen hatékony - és látványos vadászmódszernek mutatkozott, a középkorban önálló mesterségként űzték, de lassacskán egyértelműen föúri fényüzéssé vált. A magyar solymászat története a honfoglalástól a Rákóczi-szabadságharcig (1703-1711) jól követhető. A napóleoni háborúk idején Európában felszámolódtak a fóúri solymásztelepek, s a solymászatot a 19. századtól már csak tartalmas idötöltésként, ám mégis kulturális örökségként próbálják feléleszteni. Az új technika 
képviselői, a lőfegyverek, az általuk kiszorított technika képviselőinek, a solymászmadaraknak részben a szerepét és részben a nevét egyaránt átvették. (Ám egyik itt tárgyalt fegyvertípus se vadászfegyver.)

A muskéta etimológiájában említett karvaly és a terzerol etimológiájában említett héja - a sólyomfajokhoz hasonlóan - jól betanítható solymászmadár. A sólymok és általában a madarak, továbbá a fegyverek történeti szókincsvizsgálata további analógiákat tárhat fel. Így például az angolban saker 'kerecsensólyom; régi ágyúfajta' (< ófrancia és spanyol sacre < arab saqr). Ugyancsak az angolban a falcon 'sólyom', a falconet 'falkonett; gébics'. Ez utóbbi madárnem (Lanius spp.) agresszív természete magyarázza, hogy egyik elnevezése a 'sólyom' jelentésű szóból lett képezve (angol neve: shrike).

\section{Hivatkozott irodalom}

Babos Kálmán 1865. Közhasznu magyarázó szótár [...]. Heckenast Gusztáv, Pest.

HORVÁTH MÁRIA 1978. Német elemek a 17. század magyar nyelvében. Akadémiai Kiadó, Budapest. KARINTHY FERENC 1947. Olasz jövevényszavaink. A Magyar Nyelvtudományi Társaság Kiadványai

73. Magyar Nyelvtudományi Társaság, Budapest.

KITTAY, EVA FEDER 1987. Metaphor: Its Cognitive Force and Linguistic Structure. Clarendon, Oxford

Mollay KÁROLY 1982. Német-magyar nyelvi érintkezések a XVI. század végéig. Akadémiai Kiadó, Budapest.

Storfer, Adolf Josef 1937. Im Dickicht der Sprache. Dr. Rolf Passer, Wien-Leipzig-Prag.

TEMESVÁRY FERENC 1997. Fegyvertörténeti kislexikon. Középkor, kora újkor. Rubicon 8/7 (melléklet): i-vi.

KICSI SÁNDOR ANDRÁS

\section{SZEMLE}

\section{Kai Witzlack-Makarevich Hrsg., Kalkierungs- und Entlehnungssprachen in der Slavia: Boris Unbegaun zum 120. Geburtstag}

[A szlávság tükörfordító és szókölcsönző nyelvei: Boris Unbegaun 120. születésnapjára]

Frank \& Timme, Berlin, 2018. 363 lap

Az itt bemutatandó, 20 tanulmányt tartalmazó, 14 nyelven íródott ${ }^{1}$ kötet a jeles szlavista nyelvtudósnak, BORIS UNBEGAUNnak² állít emléket. A Magyar Nyelv néhány olva-

${ }^{1}$ A kötetben nemcsak a tudományos publicisztikában „bevettnek” számító angol, német vagy orosz nyelvü cikkeket találunk, de szép számmal szerepelnek olyanok is, amelyek valamilyen „egzotikusnak" tekinthető szláv mikronyelven (pl. felsőszorb, alsószorb vagy kasub) íródtak.

${ }^{2}$ BORIS OTTOKAR UNBEGAUN (1898-1973) német származású orosz nyelvtudós, nagy hatású filológus, a szláv nyelvek és irodalmak kiváló ismerője, a Ljubljanai Egyetemen oktató két híres 